\section{THE PHOSPHATE INDUSTRY.}

\section{1.-SOURCES OF SUPPLY OF MINERAL PHOSPHATE.}

\section{PACKARD.}

In pre-war days very little interest was taken in mineral phosphate except by those immediately connected with the trade, but during hostilities the high prico of foodstuffs of all kinds greatly enconraged the nse of fertilisers, and the labour conditions in all tho phosphate-producing arens created a shoriage which at one time amounted to almost a world famine. This shortage, which was apparently only temporary and due to difficulties of labour and transport, has crented a new interest in phosphate-mining, so that new deposits and rumours of fresh diseoveries are to-day mitters of world-wide interest. It only needed tho British Government to decide on conserving the phosphato resources of the Empiro by acquiring the rights of the Pacific Phosphato Company to imbue the public with the idea that phosphate mines and gold mines were equally lucrative propositions; but this has not been tho past experience by any means. The Ocean Island deposits, being of very high grade and easily mined by very cheap labour, certainly proved very profitablo to the original shareholders, but with this exception phosphate-mining has never been a very lucrative undertaking. Experience has shown that whenever consumption has overtaken production new deposits have been opened up and the shortage very soon turned into a surplus. Even to-day the existing deposits are known to contain enormous reserves in sight, which are capable of supplying the world's demands for a very considerable period.

Phosphates occur in many parts of the world, and vary in quality from a hard, rocky material, such as tho Florida hard rock and Curacao phosphates testing $75-80$ per cent. phosphate of lime, to the soft, sandy deposits of North Africa, which contain from $57-65$ per cent. of the samo constituent. No doubt large quantities of lower-grade minoral occur in different parts of thio world, but these are not generally considered workable, except in Frnnce and llelgium, where considerablo quantities testing $40-50$ per cent. are raised annually and are used extensively for direct application to the land. Owing to the rarying nature of tho deposits tho methods of mining differ very widely. Where tho phosphate occurs as a rock, at in tho Florida hard-rock deposits, blasting is of course, necessary, whereas in the Florida pebble fields, where the product is in the form of nodules or pebbles often lying close to the surface and in beds from 10 to $20 \mathrm{ft}$. thick, the overburden is stripped off by menns of excavators and the pebble washed out by water pressure. Again, in most of the North African mines the phosphate seams occur in tho sides of the hills, and the soft phosphate is dug out in galleries rumsing into the hill and following the face of the seam. In England small deposits of coprolites in tho form of hard pebbles were worked some thirty yenrs ago in the Eastern Counties, where the formation is somewhat similar to the Floridn pebblo berls, but on a very much smaller seale. Tho coprolites lay in narrow beds at various depths, and whero tho doposit was close to tho surfice digring was a simple matter, but theso nccessiblo beds were long ngo worked out. It may be interesting to noto that at the beginning of the wnr, when the scarcity of phosphates wiss first being felt, tho Admiralty anthorities were asked to, and eventually did, supply ships to convey the phosphato from North Africa, but at first they aro reported to havo pointed out that they could not see their way to do so, as the Geological Survoy showed the existence of large deposits of phosphates in England. Whather as a result of this reply or not, the Ministry of Munitions nfterwards opened un a coprolite bed and raised some thousands of tons, but tho cost proved out of all proportion to the value of the phosphate obtained.

World production of phosphate.

1) uring the ten years immediately preceding the war the demand for phosphates caused a gradunl riso in the output, which increased, according to tho statisties, from slightly under 5 million tons in 1907 to just over 7 million tons in 1913, in which year the consumption was very little short of the total production.

In 1907, as well as in 1913, the United States showed the largest output, with North Africa second, but it will be noticed from the following statistice that during that period the North African production increased at in grenter rate than that of the United States.

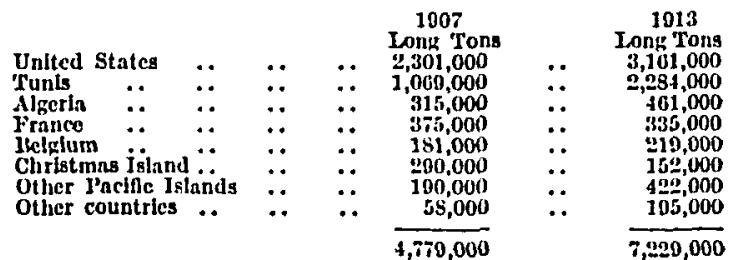

Of the quantities designated as produced by "other countries," the sources would include Egypt, Japan, Australasia, Curaçao, Russia, etc. of which Egypt contains the most important deposits.

United States.

The first phosphate deposits to to worked in America wero the South Carolina deposits, but these are now worked on a very small scale only, and in 1913 Florida and 'lemnessee produced 96 per cent. of the entiro Amerienn output. Phosphintes aro also mined on a small scale in Kentucky and A rkansas, and undeveloped deposits are known to exist in North Carolina, Alabama, Georgia, Virginia, and Idaho.

Florida hard rock.-Tho deposits of "hard rock" occur very irregularly, and ats to location, depth from the surface, extent, quality, and quantity, conform to no general rule; whereas at ono point the phosphate may lio at the surface, in other places it may be so deeply buried as to be unworkahle. The material above the phosphate is generally of a sandy, clayey nature of variable thickness. In tho Florida Stato Geolorical Survey Florida hard rock is stated to contain from 79-83 per cent. tricalcium phosphate, but expericnce of shipments tends to prove that tho rock mined contiins an a verago of 77-79 per cent. 'The hard-rock phosphato was very popular in Europo beforo the war, no doubt owing to tho facts that its higlt guality makes it economical to transport and that the deposits are all within ensy distanco of good shipping ports. Also tho low percentage of iron and alumina enables in highly soluble superphosphate to be manufactured from it without fenr of reversion. In 1913 tho ontput of hard rock nmounted to 477,000 tons, all of which was exported, but in 1919 the output was only 341,000 tons, of which 100,000 tons was consumed in America.

Forida land pebble.-The " land-pobblo" phosphates are much more easily mined than tho hard rock, and aro moro uniform in their occurrence, although varinblo from place to place. Tho phosphate occurs in beds of pebbles in a matrix of clay, sand, and soft phosphate, tho overburden consisting of sand and sundy clny. Tho beds have an avorage thickness of from 8 to $10 \mathrm{ft}$., with a maximum of 18 to $20 \mathrm{ft}$. The highest grades of pebble 
phosphate contain from $75-76$ per cent. tricalcium phosphate and tho lowest grades 62 per cent., being graded for salo as $68-70,70-72$, and 75 per cent. For consumption in America tho most popular grade is the 68 per cent., but it is difficult to understand why this should be, as the distances between the mines and tho consuming works aro often very great. Possibly the farmer may prefer a lower grade and conseguently lowerpriced superphosphate. In 1913 the ontput of pebble pliosphato was $2,107,000$ tons, of which 887,000 tons was exported, but in 1919 the production had fallen to less than 1 million tons, of which only 131,000 tons wins exported.

fiennessee phosphate.-'Tho phosphates which occur in 'Tennessee are of two kinds, known as bluo and brown phosphate, respectively. The blue phosphate is a hard, rocky phosphate testing in somo eases as high as 85 per cent. phosphato of lime, and the heds aro thin, seldom exceeding $20 \mathrm{in}$. in thiekness; the mineral contains a high percentago of iron and alumini, and is not extensively mined. 'The brown phosphato occurs in irregular deposits close to the surface, resting on limestone with an overburden of clay and sand mixed with phosphato; it is of several kinds, varying from a shelly rock to a mass of small pebbles, and has a reddish-brown colour. Tho beds averago from 8 to $10 \mathrm{ft}$. in thickness, and tho phosphato contains from 70-80 per cent. phosphnte of lime, although, of conrse, there are large deposits of much lower quality. Statistics relating to the production of 'Tenuessee phosphate are somewhat difficult to obtain, but it would appear that in 1013 the quantity mined was about 500,000 tons.

\section{North Africi.}

As regards present production, tho North African phosphate deposits aro second in importince to those of the United Stintes, but it is probablo that their extent is far greater than that of any other known deposit. Recent discoveries in Morocco show that thero is an almost continuous series of heds running aeross the wholo of North $A$ fricn from Morocco, through Algreria, 'l'unis, Cyrenaica, to Wgypt, but many of these deposits are at present undeveloped, owing chiefly to their distance from the seit and the capital which would havo to be spent in developing them. Tho Algerian deposits were the first to bo opened up, but tho Tunisian deposits havo now boen doreloped to a greater extent, and the Gafsa mines now produce tho largest annual tonnage of any singlo deposit in tho world.

\section{Alocria.}

The most important deposit in Algeria is at Dibel Kouif, near Tebessa, owned by tho Constnutine Phosphnte $C_{0}$. Tho phosphato hero occurs in beds varying in thickness from 2 to 9 ft. which lie often ono above the other between lnyers of slato and marl, tho slato forming an oxcellent roof so that galleries can bo driven into tho hillsido and tho phosphato onsily extracted. 'Tho mineral is soft, and as tho phosphate content of tho beds varies between 58 to 68 per cont., an average of $6.1-65$ per cont. can onsily bo maintained. The oulput from Constantins in 1913 was npproximately 300,000 tons, but the production is limited by the capncity of the railway to tho nearest port of Bone, which is 120 miles from tho mines. 'Tho reserves of good-ruality phosphnte in theso mines are enormous. Thio only other doposit at present worked extensively is tho deposit of M'Znita, whero the phosphate occurs in beds of 1 to $0 \mathrm{ct}$. in thicliness, contrining from 58 to 63 per cont. phosphato of lime. 'I'his phosphate has a day'k colour and is of a rocky nature, being much harder than tho Constantino quality. The total output from Algoria in 1013 is givon as
461,000 tons. Other Algerian deposits are dealt with under tho heading Undeveloped Deposits. Tunis.

Tho total output of phosphates from Tunis in 1913 is given as 2,284,000 tons, of which over 1 million tons was produced by the mines of tho Société des Phosphates do Gafsn, which, as stated above, is the largest production from any singlo mining company in the world. 'This compiny owns tho 150 miles of railway botween tho mines and tho port of Sfax, which has an excellent harbour. The phosplate is extremely soft and outerops in tho hills in beds of from 1 to $10 \mathrm{ft}$. thick, and two qualities aro produced, the lower grade testing from 58 to 60 per cent. and the higher grade 60 to 65 per cont. Tho Société des Phosphates 'Tunisiens operates tho deposits at Kana Jjerda in 'lunisia, closo to tho Algerian deposit of Djbel Kouif. Ilero tho phosphato is again of a coft, sandy naturo, containing from 57 to 60 per cent. phosphate of lime. These deposits are of more recent development than thoso of Gafsa, and a ro producing about 300,000 tons per annum. 'Tho deposits at Ifaknassy aro somewhat similar to thoso at Kiaala Djorda but of slightly higher quality, averaging 60 to 63 per cont. The only other important workings aro those of the Sociúté des Pliosphates du Dyr, from which a soft phosphato averaging 57 to 59 per cent. is obtained. 1)uring tho war the North African mines were practically tho only source of stipply for Europe, as America and tho moro distant deposits wero cut off by shipping difficulties. Labour and transport difficulties, however, reduced tho shipments to 820,000 tons in 1919 , and the pre-war output has not yet been reached.

\section{Belyium.}

Thero are considerable phosphate deposits still worked in tho neighibourhood of Mons and Liége, but tho higher grades have been largely worked out and the nrerngo grade obtained now is from 40 to 50 per cent. phospliate of lime. Tho phosphate is soft and sandy, contains a high percentago of carbonato of lime, and is used extensively for application to the land in the ground stato as a substituto for basic slag.

\section{France.}

There aro considorablo beds of soft phosphate, known as phospliatic chalk, in the Aisne, Oise, C:alais and Somme districts, carrying from 40 to 65 per cent. phosphate of lime. $A s$ in the Jelgian beds, tho higher grades a ro rapidly being worked out and the output is declining, France now looking to Nortl Africil for her phospliate requirements.

\section{Christmas Island.}

Largo deposits of phosphate of very high grade occur in Christmas Island in the Indian Ocean, and in 1913, 152,000 tons was exported. These phosphates were formed like those of the Pacific Islnnds by the combination of organic materials with the calcareous rock, and contain over 80 per cent. tricalcium phosphate.

I'acific Islunds.

Tho Islands of Nauru, Ocenn Island, Angaur, and Miaknten exported in 1013 over 400,000 tons of high-grade phosplatato containing from 80 to 85 per cent. of tri-calcium phosphato, Ocenn Island contributing 180,000 tons. I'lieso deposits aro similar to those of Christmas Island, tho phosphato being soft and lying closo to tho surfaco; and if it wero not for the relative inaccessibility of the Islands tho output would bo far greater. They aro probably tho largest doposits of very high grado phosphato which aro known. Nauru is believed to possess reserves of 80 to 100 million tons and Ocean Island 50 million tons. Beforo the war Nauru and 
Angaur belonged to Germany but aro now adadministered by Groat Britain and Japan, respectively. A good deal of attention has lately been attracted to Nauru on account of the Government schome for working the deposits in conjunction with tho $\mathrm{New}$ Zealand and Australian Governments. Let us lopo that this experiment in Government trading may bo less expensive than somo others have been.

\section{Egypt.}

There are extensive phosphate beds in Egypt and in 1913 over 100,000 tons was produced, of which 60,000 tons was exported. In the Sebain district of the Nile Valley there are large quantities of phosphato lying close to tho surfaco in beds from 18 in. to $6 \mathrm{ft}$. thick, but tho phosphate only averages 45 per cent. phosplante of lime. At Safaga, on tho Red Sea, there aro considerable deposits running as high is 75 per cent. which aro only 18 miles from the sen. There aro also largo deposits of lower-grado pliosphates in this neighbourhood, but they are not worked at present; the mineral outcrops in tho hillsido and, being soft, is easily worked. Thero aro also extensivo deposits lower down the Red Sea near Kosseir which are being doveloped, and there is no doubt that a vory largo quantity of phosphate is availablo in this rogion.

\section{Undeveloped deposits.}

If any doubts existed concerning a sufficiency of phosphate for the world's requirements for many yenrs to como, they should havo disappeared after the important discoveries mado during the war. The most promisine of these is in Mlorocco where dovelopment has already commenced and sample shipments are early expected. These deposits aro situated at El-Beroudj, about 80 miles south-enst of Cusablanca, and are snid to contain hundreds of millions of tons of phosphate. The beds occur in tho Beni Meshino Pliteau beneath limestono and rary in thickness from 4 to $6 \mathrm{ft}$. Somo of the plosphato is lolieved to contain as much as 75 per cent. calcium phosphate, and if the lutk proves to be as rich as this, the deposit will be a very valuable ono for European requirements.

Iarge deposits of pliosphates wero prospected in Palestine during the year 1916 by a German professor, who roported that the discoveries wero very important, and the fact that a military railway has been sinco constructed running very close to the deposit may have an important bearing on ito development. It one point borings slowed a doposit of great thickness, approximately $65 \mathrm{ft}$. with an avernge test of 72 per cent. and in places 83 per cent. phosphate of limo. Thero appear to bo many deposits in Palestino of an unusual thickness varying in phosphate content from 62 to 83 per cent., and, if reports bo correct, it should not bo long before these beds aro developed on a largo scalo.

Another largo deposit which has not yet been doveloped is known to exist at Djebel Onk in Algeria, 50 miles south of 'Tobessa. This doposit would be depondent on the Telsessa-Bono railway, which appears to bo only capable of dealing with the present traffic, but it is reported that an extonsion is contemplnted to Djebol Onk. These deposits aro estimated to contain at least ono thousand million tons of phosphate averaging $00-$ 70 per cent., and must bo looked upon as very important.

It has been impossible in the spaco availablo to donl with overy known phosphatic deposit in detail, but all the moro important havo been referred to in an attempt to show tho magnitudo of tho industry which has arison from Lawes' first experimonts in dissolving coprolites.

\section{SOCIETY OF CHEMICAL INDUSTRY.}

\section{MEETING OF COUNCIL.}

A short meeting of tho Council was held on August 5 to transact certain routine business prior to the departure of the President for Canada. Sir Villiam Pope stated that ho had received a letter from Monsieur P. Kestner intimating that the Annual Meeting of the Sociétó do Chimie Industrielle will be lield in Paris from October 9 to 12, and asking that the Society would send a number of delegates; a few members of Council had already undertaken to attend the meeting, and he hoped that others would send in their names.

\section{NEWS FROM THE SECTIONS.}

\section{O'THANA.}

The annual meeting was held on ipril 1.4, with Mr. If. J. Hambly in the chair. 'The hon. secretary, Mr. S. J. Cook, read his report which intimated, inter alia, that Mr. E. Stansfield, the chuirman of the Section, had sovered his connexion with the Departmont of Mlines, in which he was chief engineering chemist of the Fuel-T'esting Division, and had gono to tho University of Alberta to take up some special research work on the utilisation of the lignite-coals in that provinee.

During tho past session the Section has held 0 meetings (exclusivo of tho immual meeting), at which the average attendance was $4.4-a n$ improvement upon the previous vear. At the opening meoting, Mr. H. H. Claudel, manager of the General Enrineering Co., rave an address on "Mlineral Flotation Processes." The meeting in December wns dovoted to an address by Mr. R. I'. Fiworthy on "The History and Manufacture of Helinm." At tho third meeting a kinematograph film portraying the Story of Conl was shown; at the fourth, Mr. P. I. Jeek described tho operations of tho British America Nickel plant at Deschenes, and subseruently the member's visited tho plant and made a thorough inspection. Tho subject of "Vitamins" was discussed at tho January meeting, "Cements and Super-cements" at the February meeting, and at tho last meeting Mr. 1F. Ji. Isthe, chief chemist to the British Anerica Nickel Corporation, gare a lecture on "Principles underlying Copper-Leaching and Precipitation."

Juring the past session the Section cnrolled 17 now members and 30 Associates, which compares with 15 members and 32 Associates in tho year 1919-20. 'T'ho most important event of the year was the dissolution of the Canadian Section of tho Society and the establishment of five independent Sections, of which Ottawn is one.

Taken in roview, states tho report, the past year may bo considered successful, nlthough it may bo open to question whother in futuro it will be desirable to hold so mnny joint meetings with other societies as wore held this session. The tendency, when this is dono, is for somo of the members of the Socioly to consider themselyes rolieved, as it wero, of their responsibilities. It seems desirnble, thercfore, to suggest that the incoming Committce should seek to strengthen the position of the Section, and, in viow of the visit of tho parent Society to Canada this year, it will probably be found essential for overy momloer in Canada to exert himself in the interests of the Socioty in order that the desired results niay bo attained.

Mr. F. J. Hambly was elected chairman of tho Section for tho ensting yenr, Mr, S. J. Cook was re-electod hon. secretary, and ats the result of a ballot tho following were clected to serve upon the 